\title{
Policy Implementation of Environmental Impact Assessment (EIA) (Case Study on Mining Activities in Gorontalo Province, Indonesia)
}

\author{
Andris Amir ${ }^{1} \quad$ Arifin Tahir $^{2} \quad$ Ansar $^{3} \quad$ Sastro Mustapa Wantu ${ }^{4}$ \\ 1.Goverment Employees in Local Government of Pohuwato,Gorontalo, Indonesia \\ 2.Public Administration Department, Economic and Business Faculty, Universitas Negeri Gorontalo, Indonesia \\ 3.Education Management Department, Education Science Faculty, Universitas Negeri Gorontalo, Indonesia \\ 4.Pancasila dan Civic Education Department, Social Science Faculty, Universitas Negeri Gorontalo, Indonesia
}

\begin{abstract}
The purpose of this study is to explain the implementation of EIA policies by Mining Companies in Gorontalo, Indonesia. This study uses a case study research design by conducting participatory observations, in-depth interviews, and documentation on the phenomenon of EIA policy implementation in Gorontalo. The results of the study were analyzed descriptively qualitatively. The results of the study found that the implementation of the EIA policy in Gorontalo was predominantly intervened by the government with a command-and-control approach starting from the process of issuing environmental permits to regular supervision carried out to measure the level of compliance of mining companies in monitoring and handling ecological impacts. However, community participation was only involved in scoping mining activities and assessing EIA documents. In its implementation, mining companies are less open and responsive to the local government and overlapping supervision between provincial and district governments.
\end{abstract}

Keywords: Implementation, Environmental Impact Assessment, Mining Activities

DOI: $10.7176 / \mathrm{PPAR} / 9-6-06$

Publication date:June $30^{\text {th }} 2019$

\section{INTRODUCTION}

Current development policies cannot separate from environmental aspects considerations. The integration between development policy and environmental policy has become a concern, and a global agenda that began since the conference on The Human Environment conducted in 1972 in Stockholm, Sweden which presented 113 countries and representatives of 19 international organizations. This international conference addresses explicitly environmental issues, which try to articulate the relationship between environment and development even though in some cases there are contradictions between prioritizing the environment and the economy, but both recognized as two sides of a coin that cannot be separated. One of the results of this Conference was the establishment of the United Nations Environmental Program (UNEP) which has a mission to encourage leadership and partnerships to protect the environment by providing inspiration, information and enabling countries and people to improve their quality of life without sacrificing the next generation (Vogler, $2007: 432$ ).

UN Conference on Environmental and Development (UNCED) in Rio de Janeiro, Brazil (1992), which confirms the importance of the relationship between environment and development and clarify the agenda of sustainable development (sustainable development) in the world (Paul, 2008: 578). This agenda resulted in 17 Principles in the Rio Declaration on Environment and Development also calling for the use of EIA as a national decision-making instrument to use in assessing whether the proposed activities tend to have significant adverse impacts on the environment. It also emphasizes the role of government authorities who are competent in the decision-making process. Another principle of this declaration that is relevant to the practice of EIA is the application of the precautionary principle (Ogola, 2007).

In Agenda 21 which is also the result of this convention proposed that the government must: (1) Promote the development of appropriate methodologies to make integrated energy, environmental and economic policy decisions for sustainable development, including through environmental impact analysis. (2) Develop, improve and implement ecological impact assessments, to encourage sustainable industrial development. (3) Perform investment analysis and feasibility studies including environmental assessments to establish forest-based processing companies. Introducing EIA procedures that are appropriate for the proposed project may have a significant impact on biodiversity, providing information that is suitable to be made widely (Ogola, 2007)

Previously, the practice of development policy that paid attention to environmental aspects first devised by the United States adopted by various countries in the World, including Indonesia in 1987 (Petts, 1999: 4). Development policy integration with environmental policies has been carried out since the issuance of Law No. 4 of 1982 concerning the Principles of the Environment which provide the same guidelines and understanding from all stakeholders regarding the environment. This Act later developed into Law No. 23 of 1997 concerning 
Environmental Management which provides direction for environmental management activities in Indonesia developed into Law No. 32 of 2009 concerning Environmental Protection and Management. Therefore, in general, the responsibility for environmental management rests with the government, in the sense that it is not handed over to individual citizens or becomes a civil law. The burden of environmental management is in the government which brings consequences to the institution, and the authority for the government to conduct ecological management becomes part of administrative law (Muhjad, 2015: 6).

Environmental management is a conscious effort to maintain and improve the quality of the environment so that basic human needs can be fulfilled as well as possible. The industrial revolution caused developing countries including Indonesia to continue to spur the growth of the industry in their country because it was considered as a guarantee of long-term economic growth, increasing state revenues and being able to solve unemployment problems. So that it is not denied that the industrial sector does give a little enlightenment to the Indonesian economy, but the high industrial development can also threaten the environment and society if it not accompanied by efforts to prevent environmental destruction (Bhandari \& Garg, 2016; Resosudarmo et al., 2008). One of the preventive measures taken is to require every industry player to have an environmental permit by including the Environmental Impact Assessment (EIA). Through these obligations, it is expected to be able to encourage the awareness of the employers to study project development plans that are environmentally friendly Without environmental permits plans for activities and businesses such as mining, industry, or other activities that have the potential to affect the environment cannot implement. EIA is the process of integrating sustainable development with environmental insights in project decision making towards policies, plans, and activities, through anticipating possible negative impacts on the environment. Evaluating the extent to which EIA to be published has the potential: increasing the risk of climate change; increase biodiversity damage, deterioration or extinction; increasing the intensity of floods, landslides, droughts, and forest and land fires. Especially in areas where conditions have classified as critical. Reduce the quality and abundance of natural resources, especially in areas where states have classified as essential. Encourage changes in the use and / or conversion of forest areas, especially in areas where conditions have classified as critical; increasing the number of poor people or threatened livelihood sustainability (livelihood sustainability) of a group of people; and / or increase risks to human health and safety (Article 4 of Minister of Environment Regulation No. 27 of 2009).

Preventive efforts through EIA on the occurrence of pollution and environmental damage due to particular businesses or activities (Yakin, 2017) are also the basis for improving environmental quality and environmental management within the framework of realizing sustainable development as embodied in Law Number 32 of 2009 about environmental protection and management. Sustainable development affirms the three pillars of sustainable development, namely economically viable, socially acceptable, and environmentally sound (Hens \&Nath, 2003). The development process carried out in this way is expected to improve the welfare and quality of life of present and future generations (Explanation of Government Regulation Number 27 of 2012).

At present, the Indonesian Environmental Performance Index categorized as low as shown in the results of the Environmental Performance Index (2018) based on two main dimensions, namely environmental vitality and environmental health with a score between 0-100. The assessment results show that the environmental performance index in Indonesia is far in rank 133 of 180 countries with a score of 46.92. Value vitality of Indonesia environment scored 46.92, while ecological health reaches 45.44. The position is quite far from Malaysia which is in the order of 75 with a score of 59.22 and Sweden is ranked 1 with a score of $87.42 \%$ (EPI, 2008). The results of this assessment indicate that environmental problems or environmental management in Indonesia are still a severe problem that needs to analyze the issues and the management quality developed.

The quality of environmental management becomes an increasingly strategic policy issue because it has broad implications in political, social, cultural life and others. In economic life, the quality of environmental management will be able to improve the investment climate to enhance economic growth as expected by the community. In political life, public services have vast implications in strengthening the government trust level. Because the quality of environmental management is getting better, can affect community satisfaction so that public confidence in the government increases. While from the socio-cultural aspect, quality environmental management has an impact on people's psychology such as generating mutual respect, raising awareness among others and always encouraging people to do positive things, act rationally and obey applicable laws (Ministry of Law and Public Relations Bureau Environment, 2012).

In managing the environment, there has been a change in development strategy since the enactment of regional autonomy since 1999, making the most significant responsibility lies with the local government which has given the authority to grant permits for exploration and exploitation of natural resources in the government or individuals or the private sector. The enthusiasm of development that is so great in the region also needs to be rewarded with great attention to the environment around it so that sustainable development realized. To make this happen, the consequences of the environment requires to obtain permission from the government after having EIA (Law No. 32 of 2009).

You are granting environmental permits by Government Regulation No. 27 of 2012 concerning 
Environmental Permits. Minister of Environment Regulation number 08 of 2013 concerning Management of Assessment and Examination of Environmental Documents and Issuance of Environmental Permits as one of the policies made by the government must pay attention to the impact of being granted such permits, such as environmental, sociological, community, economic conditions, and legal certainty. Environmental management efforts at the level of project activities through the EIA instrument must pay attention to ecological aspects and realize sustainable development goals (Mekuriaw\&Teffera, 2013).

In Gorontalo Indonesia, the mining companies had a significant impact on the environmental damage that conducts gold, mineral, metal and followers mining activities. The existence of this mining company is considered to have a more significant impact on the environment in which the company operates (Wantu, 2012). Not surprisingly, until now, the company's operations have still been rejected by several people in Gorontalo Regency.

Some studies show that mining companies engaged have more significant negative impact on the environment than positive like as mining waste, lack attention to the natures conservation, the area of a former mine that left gaping, mining forests, conflict between the community, triggering the mud flood into the community's agricultural sector, transferring the function of the arable land to the area miners, reduced sources of income and community livelihoods (Abdul Hafiz, 2016; Risal, et al, 2013) — of the change in topography, opening a large hole, disruption of hydrology, air quality decline and the loss of natural ecosystems (Fachlevi, et al. 2015).

But have not found studies that look at the implementation of the EIA policy of environmental aspects of the process of issuing licenses and supervision of the government apart from the assessment of compliance of the company. For this reason, this research is essential to explore the implementation of policies from the dimensions of the process of issuing environmental permits, company compliance in implementing EIA and government supervision in Gorontalo Province, Indonesia.

\section{LITERATURE REVIEW}

\section{Environmental Policy}

Public policy is what you have ever chosen to do or not to do (Dye, 2008). Public policy is not because the plan has promulgated, or the project implemented by the public, but the contents of the system itself which concerns the public interest or general welfare (Arifin \&Rachbini, 2001). The main objectives of public policy are: first, to distribute national resources, which include redistribution and absorption of national resources. And tax is an absorption policy or also called extractive policy. Absorptive systems aim to support distribution (and redistribution ) plans, such as social subsidies, poverty eradication, housing, and health care. Second, the purpose of public policy is to regulate, liberalize and deregulate (Kolb, (1978: 226) Regulatory policies aim to regulate, govern, create control, standardize, legalize and harmonize, while deregulation seeks to release, relax, stop, or free any regulative policy (Nugroho, 2014: 57).

Anderson (2003: 7-11) confirms that policies divided into three types, namely distributive policies, regulatory policies, and redistributive policies. The distributive strategy involves the allocation of services or benefits to specific segments of the population - individuals, groups, companies, and communities. Regulatory policies impose limits or restrictions on individual and group behavior. That is, they reduce freedom or freedom of action from those who are regulated, whether bankers, utility companies, meat packers, or salon owners. In this case, they are different from distributive policies, which increase the freedom or wisdom of the affected person or group. Self-regulation policies or self-regulation policies are similar to competitive, regulatory policies because they involve limiting or controlling some things or groups. However, unlike competitive, regulatory policies, selfregulation policies are usually more controlled by regulated groups as a means of protecting or promoting the interests of their members. Redistributive policies involve deliberate efforts by the government to shift the allocation of wealth, income, property, or rights among a broad class or population groups, such as rich and poor, proletariat and bourgeoisie. "The purpose involved is not the use of the property but the property itself, not the same treatment but the same ownership, not behavior but becomes. The issue of public policy needs conceptualizing as a form of government regulation that regulates corporate and individual expression. Company behavior regulation is a crucial target in the system and regulatory environment (Cohen, 2006: 30).

Environmental policy is the concept of environmental pollution is part of public policy relating to public opinion which was first born in the United States of America from former vice-president Al Gore originated from the publication Rachel Carson with the title "Silent Spring" published in 1962. This publication made a lot of parties are aware of the harmful effects of pesticides on agricultural production so that foster social awareness about the environment that is high in the United States (Pellikaan\& Van der Veen, 2004: 3). In 1969, the Congress in the United States succeeded in passing the National Environmental Policy Act or NEPA, which emphasized that every large-scale project must be considered environmentally through the concept of the Environmental Impact Assessment. (Jordan \&Lenschow, 2008: 289).

\section{Environmental Policy and Sustainable Development}

Brundtland Report provides the most popular ideas about sustainability (sustainable development), the 
development-oriented to meet the needs of the present without ignoring the interests and needs of future generations (WCED, 1987). Environmental policy is intended to realize sustainable development. Sustainable development enables the achievement of personal satisfaction and improvement in the quality of life with ecosystems and species that are appropriately utilized and sustainably (Allen, 1980). Baumgartner and Quaas (2010) assert that sustainable development is normative ideas about how humans should act towards nature, and are responsible for their actions and for future generations. Kates et al. (2001) emphasize that the core of sustainable development is to meet fundamental human needs while preserving the life support systems of planet Earth.

Gasparatos, et al. (2008) suggest that the assessment of sustainable development is: (1) integrating economic, environmental, social and institutional improvement issues and considering dependencies among these aspects; (2) examine the consequences of current actions into the future; (3) acknowledging uncertainty about the results of our present activities and acting with precautionary preconceptions; (4) involving the public; (4) include consideration of fairness of intergeneration and intergeneration .

Meanwhile, Baumgärtner and Quaas (2010) the general form of sustainable development is: (1) the subject's focus on the relationship between humans and nature. (2) orientation towards inherently long-term and uncertain futures. (3) the normative foundation in the idea of justice, between the present and future human beings and between humans and nature. (4) attention to economic efficiency, understood as non-wasteful, in the allocation of essential goods and services as well as human-made substitutes and supplements.

\section{Environmental Impact Assessment (EIA) Policy}

EIA is part of environmental policy. Siahaan (2008: 189) explains that the EIA is one of some instruments adopted to achieve and maintain sustainable development (sustainable development). This definition sees the instrument in general as a tool or instrument to realize sustainable development. In the context of sustainable development, emphasizing on the three main pillars, namely economic, environmental and social, then one concrete step is that every economic activity to meet needs or benefit does not neglect the first, aspects through Environmental Impact Analysis as a preventive measure. Meanwhile, Munn (1979) views EIA in terms of needs, " EIA is a need to identify and predict impacts on the environment and human health and well-being from legislative, policy, program, project and operational procedures proposals and to interpret and communicate information about their impacts."

In that context, EIA becomes something that must fulfill from every planned activity or specific business in the form of proposals, policies, programs, projects to operational procedures. Furthermore, Rahmadi (2011: 9) sees EIA as a review process, analysis of a method of utilizing natural resources. EIA is an effort or approach to assessing whether the use or management of natural resources or government policies will have an impact on the environment (Rahmadi, 2011: 9). While other definitions view EIA as a result of a study of the environmental effects of a particular business plan or activity, as stated by Mustofa (2005: 8) " EIA is the result of a study of the important impacts of planned business or activities on the environment in a single ecosystem stretch and concerning the authority of one responsible agency "

From some definitions in this study, EIA as a result of an analysis of the environmental impact of a business plan or project carried out by a particular institution. EIA is a need to utilized in second, management. Historically, EIA was first born with the introduction of environmental laws called the National Environmental Policy Act (NEPA) by the United States in 1969. NEPA entered into force on January 1, 1970. This law states that all legislative proposals and sizeable federal government activities that are expected to have a significant impact on the environment are required to be accompanied by reports from the Environmental Impact Assessment.

World Conference with the name of the UN Conference on Environmental and Development (UNCED) in Rio de Janeiro, Brazil (1992) became the main driving forces confirmed the importance of the relationship between environment and development and clarified the agenda of sustainable development (sustainable development) in the world (Paul, 2008: 578) and emphasizes the application of EIA Policy in every country in the world. EIA is used as a national decision-making instrument to be used to assess whether the proposed activities tend to have significant adverse impacts on the environment. It also emphasizes the role of government authorities who are competent in the decision-making process. Another principle (15) of this declaration that is relevant to the practice of EIA is the application of the precautionary principle (Ogola , 2007).

EIA quickly spread in developed countries which was then followed by developing countries with many parties who had felt that EIA was a powerful tool to avoid more severe environmental damage due to human activities. By referring to NEPA, for the first time in 1982 Indonesia. Adoption of EIA was carried out by various countries in Asia and Europe such as Australia (1974), Thailand (1975), France (1976), Philippines (1978), Israel (1981), Indonesia (1987) (Petts, 1999 : 3). In Indonesia since the issuance of Law No. 4 of 1982 concerning Environmental Principles which have provided the same guidelines and understanding from all stakeholders regarding the environment. This Act later developed into Law No. 23 of 1997 concerning Environmental Management which provides direction for environmental management activities in Indonesia which developed 
into Law No. 32 of 2009 concerning Environmental Protection and Management.

Since then, EIA has even felt more critical, especially EIA has become a principle of the Millennium Development Goals (MDGs) - namely ensuring environmental sustainability - determining one of the essential targets to be achieved, namely: integrated tenets of sustainable development in policies, plans and programs and reduced damage to natural resources. Setting these targets has led to EIA increasingly adopted by various developed and developing countries.

\section{Implementation of EIA policies}

Anderson (2003: 7) divides policy kind into four types, namely regulatory policies, self-regulatory policies, distributive policies, and redistributive policies. EIA policy categorized of regulatory policies that impose restrictions or restrictions on individual or group behavior (Anderson, 2003: 8). Direct regulation is a policy that retained earnings inherently prescriptive in emission standards, industrial product, and process specifications as well as the transparency and reporting requirements. Regulators can switch to the mechanism of the commandand-control when there is not enough information to create market-based instruments, or if they are functioning in a weak market where the profits of any sort will be neutralized or followed by cost (Madarang, 2014).

Command-and-control is a type of traditional policies, most often applied in practice. This policy regulates environmental permits, standards, product restrictions, and other restrictions. Environmental permits regulate the behavior of the company's environment, either by recommending the right technology or by limiting pollution. Making standards controls of the environmental characteristics of production equipment or products and prohibits overriding the use of specific products or substances Han Vos, 1997). This type of policy describes a process in which the government orders regulated parties to act in a certain way and then uses a legal system to control behavior that is not by the rules (Cohen, 2006). The application of this policy types based on the assumption that the company will act in a way that is environmentally responsible only if implemented directly by government regulations (Fiorino, 2009).

According to (Wibisana, 2017) the use of a direct regulation policy model or command-control approach shows the amount of government intervention in environmental policy in Indonesia. This form of response according to Ogus (2004) as cited by Wibisana (2017) is divided into three levels of intervention as shown in the following figure:

\begin{tabular}{|c|c|c|c|c|}
\hline \multicolumn{5}{|c|}{ Degrees of Intervention } \\
\hline \multicolumn{3}{|c|}{ 世Low } & \multicolumn{2}{|l|}{ High $\rightarrow$} \\
\hline \multirow[t]{2}{*}{ Information } & \multicolumn{3}{|c|}{ Standards } & \multirow{2}{*}{$\begin{array}{c}\text { Prior } \\
\text { Approval }\end{array}$} \\
\hline & Target & Performance & Specification & \\
\hline \multicolumn{5}{|c|}{$\begin{array}{l}\text { Figure 1. Degrees of Government Intervention } \\
\text { Source: Anthony Ogus in Wibisana (2017:164) }\end{array}$} \\
\hline
\end{tabular}

The lowest level is information regulation (regulation information ) as the small form of intervention because the government only requires individuals to provide information in the form of reports to the government or the public. Then the next level is a standard or quality standard consisting of target standards, performance standards (output) and standard specifications (processes). While the highest level is prior approval as the largest of government intervention. In this context, individuals or groups from carrying out activities unless they get permission or consent from the government.

For this reason, in this study, the implementation of the EIA policy in Gorontalo was seen from three dimensions, namely the issuance of mining permits, company compliance in monitoring and managing the environment, and government supervision of the implementation of EIA.

\section{Issuance of Mining Permits}

Licenses according to Spelt and Ten Berge as quoted by Rithi\&Pudyatmoko (2016) constitute an agreement of mastery based on a Law or Government Regulation, for in certain circumstances deviates from the provisions of the prohibition of legislation (permission in the strict sense). Authorization to obtain normative power only from the government and therefore also supervised by the government as the licensor. The government is the main agent in terms of licensing as well as potentially changing actors: those who may not be permissible, and those who have been permitted may have their licenses revoked. An act or activity permitted often considered an act or action that is prohibited by the rules. Permits issued for interpreted as "acquisition" of operations that are forbidden. The permission connotation then becomes negative. The meant forbidden when there is no permit (Rithi\&Pudyatmoko , 2016).

Permits understood in two scopes, and namely first, in the broadest sense, permission is an agreement from 
the authorities based on the rules of the Law or Government Regulations to in certain circumstances deviate from the prohibition provisions of legislation; second, in a narrow sense, binding to permit regulation. It based on the desire of the legislator to achieve a particular order or to deter adverse conditions (NM Spelt \& JBJM Ten Berger in Hidayat \&Basuki, 2014) . Permission defined as a unilateral government action based on legislation to be applied to particular events according to specific procedures and requirements (Hidayat \&Basuki, 2014) .

Permission is a juridical instrument used by the Government to influence citizens to want to follow the recommended ways to achieve a concrete goal (Ridwan , 2007: 217). Regarding the purpose of licensing, this depends on the concrete reality it faces. The diversity of Fiorino, events causes submission, in the of the permit, which in general mentioned as follows: (1). Desire to direct. (2). Licenses prevent harm to the environment. (3) The desire to protect particular objects; (4). Permission shares small objects; (5). The permit provides direction by selecting people and activities, after fulfilling Ogola, requirements (HR Ridwan, 2007). The motive of the environmental permits to ensure the protection of environmental quality through controlling behavior or specific activities of the community in general (Rithi\&Pudyatmoko, 2016). According to Michael Kloepfer that an environmental permit is an administrative tool juridical control of each activity or work done in the legislation mentioned have the license. The aim is to protect the quality of the environment through behavioral control (Rithi\&Pudyatmoko, 2016: 265).

\section{Company Compliance in EIA Implementation}

The company's compliance with the implementation of EIA is a manifestation of the implementation of a command-and-control approach in environmental policy. Hrebicek et al. (2010) suggested that the indicators of the performance of the company's environmental management are: (1) material efficiency; (2) energy efficiency (3) Water management; (4) waste management; (5) biodiversity; and (5) emission into the water.

The performance of Environmental Management by Companies that obtain EIA in Indonesian based on two main criteria, namely compliance criteria and more than required aspect assessment criteria .

a) Assessment of compliance aspects, including: Environmental documents and environmental permits:

(1) Water pollution control;

(2) Air pollution control, and

(3) Management of hazardous and toxic waste

b) Rate aspect more than the required ( beyond compliance ), include:

(1) Environmental management system

(2) Utilization of resources consisting of:

(a) Energy efficiency

(b) Hazardous and toxic materials reduction, and utilization;

(c) Reduce, reuse and recycle (3R) non-hazardous and toxic materials;

(d) Reduction of air pollution;

(e) Conservation and abatement of water pollution loads; and

(f) biodiversity protection;

(3) Communities empowerment. (Minister of Environment Regulation No. 06 of 2013)

Minister of Environment Regulation No. 6/2013 is a manifestation of the operationalization of Law No. 32 of 2009 concerning Environmental Protection and Management and Government Regulation No. 27/2012 concerning Environmental Permits

\section{Supervision of Regional Government in the Implementation of EIA}

Government oversight is a consequence of granting permission given to assess the level of company compliance and make corrections (Rithi\&Pudyatmoko, 2016). Theoretically, supervisory activities are related to the process of determining what must achieve, namely the standard, what do, namely implementation, assessing implementation and if necessary make improvements so that implementation is using the plan that is aligned with standards (GR Terry in Hasibuan, 2005: 242).

Theoretically, the enterprise as a business entity has the desire to make a profit (rent seeking) as much as possible, so it is assumed to ignore the damage caused by the business activities of his (Fiorino, 2009). Government oversight shows the magnitude of government intervention in the implementation of EIA in Indonesia.

Supervision is carried out by authorized SKPD and functional officials in the field of monitoring. This is regulated in the Minister of Environment Regulation No. 08 of 2001 which explains that environmental supervision is an activity carried out directly or indirectly by the Environmental Supervisory Officer and Government agency to determine the compliance of the business person responsible for and/or operations against the provisions of laws and regulations to control pollution and or damage living environment. Functional officials or personnel who carry out environmental supervision in the area are civil servants who are in institutions responsible for the regions that meet specific requirements and are appointed by the Governor / Regent / Mayor.

\section{METHODOLOGY}

This study uses a type of case study research with a qualitative approach to explore and describe the 
implementation of EIA policies in Gorontalo, Indonesia. The research focused on three dimensions of EIA implementation, namely: (1) issuance of environmental permits for mining companies, in Gorontalo; (2) company compliance with EIA implementation, and (3) government oversight of company compliance in the implementation of EIA.

The collection of data is done through observation participatory, documentation and conduct interviews of the informant received from the government, mining companies, non-governmental organizations in the environmental field and the people who work in the area of mining activity. The results of this study were then analyzed descriptively qualitatively using interactive miles and Huberman analysis techniques (2014), namely data condensation, display data and conclusions.

\section{RESULT AND DISCUSSION}

In general, this study found that the implementation of the EIA policy in Gorontalo took the form of company compliance with environmental regulations. Direct policy or command-and-control approach and public involvement very strong applied in Indonesia area to control the behavior of companies from actions that damage the environment.

\section{Issuance of Environmental Permits}

Environmental permits are the initial process of EIA implementation in Indonesia. The results of the study indicate that the process of issuing environmental licenses is carried out based on Law No. 32/2009 concerning Environmental Protection and Management, Government Regulation No. 27/2012 concerning Environmental Permit and Minister of Environment RegulationNo. 8/2013 Governance and Environmental Document Examination and Issuance of Environmental Permit. The provisions of this legislation govern the process of submission, assessment, and determination of the document environment, covering Document TOR Environmental Impact Statement, EIA Document, and Environmental Monitoring Plan Document - Environmental Management Plan.

The scoping process, submission, appraisal, until feasibility determination takes place rigidly based on the regulatory mechanism. The assessment was carried out by the EIA Assessment Commission whose task was to assess the Terms of Reference, Environmental Impact Analysis, Environmental Management Plans and Environmental Monitoring Basuki, based on the mechanisms stipulated in the legislation and aspects assessed in EIA documents - formed by the government with the task of conducting an EIA document feasibility assessment (Law 32/2019). This practice is an embodiment of the approach command-and-control in environmental policy in Indonesia. Michiel A. Heldeweg and René JGH Seerden quoted by Wibisana (2017: 162) assert that this approach indicates the unilateral setting of standards and obligations by the government, which will then regulate how the community must act. In the Government, the case determines the target of specific environmental conditions and the communities works in according to these rules. Arrangement of rules created through the presence (threat).

In the perspective of a public interest, this form of policy is appropriate which can be justified because with this intervention it is useful for the public interest (Wibisana, 2017). In public choice theory also explained that individual preferences are reflected the system of voting ( voting) or other procedures adopted by public institutions to produce collective choices, or to evaluate the consequences of those choices on social welfare. This theory assumes that behavior in the political world is not much different from the behavior of individuals on the market. Both act to maximize profits from individuals. The relationship of the exchange of goods / interests that forms the basis of the market system is a relationship that forms the base of the political arena (Ogus in Wibisana, 2017).

Public choice theory has three perspectives on regulative policies, namely: (1) regulation as an extension of the interest group. (2) Law as an embodiment of bureaucratic interests and (3) regulation as a regulatory tool to seek income (Wibisana, 2017). The process of issuing environmental permits is a form of government intervention in the form of regulations, standards, or licenses that serve to serve the interests of particular groups/industries. Factually, it shows that there is preferential treatment of government bureaucracy towards the company describing its position as an interest group, and in it, there are bureaucratic interests.

Although in the process of issuing environmental permits it was found that there was involvement of the community in scoping the business activity plan and evaluating EIA documents. Public engagement is intended to encourage transparency and accountability in the implementation of environmental permits for mining companies in Gorontalo. In the process of scoping the company's activity plan, community involvement is carried out through socialization and public consultation. While in the EIA document assessment ). Community involvement is carried out at the stage of consultation and input through recommended representatives. However, the final decisionmaking authority remains in the EIA Assessment Committee. For this reason, if confirmed by Arstein's theory of participation (1969), community participation in the issuance of environmental permits in Gorontalo is at the second level, namely the involvement of tokenism, namely activities to provide information, consultation, and placement. The highest level of public participation is citizen power in the form of partnerships, the delegation of 
authority and control of the public.

\section{Compliance of Mining Companies in the Implementation of EIA}

Company compliance in the implementation of EIA describes from four aspects, namely ownership of environmental permits, respect in the implementation of monitoring and handling of water pollution, control and processing of air pollution and management of B3 waste as Wibisana (2017), in the Minister of Environment Regulation No. 06 of 2013 concerning Assessment Programs Ranking of Company Performance in Environmental Management. The results of the study indicate that the Mining Company in Gorontalo is entirely compliant in implementing EIA, it describes from the ownership of environmental permits and the implementation of observations and management of water pollution, and the provision of storage places for B3 waste.

From the aspect of the environmental permit, the company has an environmental license related to gold mining activities and associated minerals. Among them are borrowing and use of forest areas permits to transport equipment, materials and products, and others. While the handling of water, air, and B3 waste pollution is also carried out through monitoring the quality standards and handling pollution reported every six months to the Regency and Provincial governments through the Environmental Agency. Environmental management is a demand of the environmental regulations in Indonesia, including Law No. 32 of 2009 concerning Protection and Management of the Environment, Government Regulation No. 27 of 2012 concerning Environmental Permits and Government Regulation No. 101 relating to Management of Waste Hazardous and toxic materials and some other derivative regulations.

This company compliance is part of the implementation of environmental policies that use a command-andcontrol approach. Vos (1997) explained that " command-and-control " is a type of traditional system, most often applied in practice. This policy regulates environmental permits, standards, product restrictions, and other restrictions. Environmental permits regulate the behavior of the company's environment, either by prescribing technology or by limiting pollution. Making standards of the control characteristics of production equipment or products and prohibit overriding the use of certain products or substances.

\section{Government Control of company compliance}

Supervision is a logical and normative consequence of the government as a licensor to mining companies as recipients of environmental permits (Rithi\& practice 2016). The results of the study show that government oversight of company compliance is carried out with three approaches, namely direct, indirect and incidental supervision. Direct supervision is carried out through field observation by a team or control assigned by the government every six months. The company also reports on the results of monitoring and handling environmental impacts to district and provincial governments every six months classified as indirect forms of supervision. Whereas incidental observations are carried out when there are cases reported or encountered about environmental impacts that are beyond the previous plan or control.

However, in general, information about company compliance is obtained by the government through semester reports provided by the company. Direct observation to the field has not been optimal because in addition to not being supported by regional functional supervisors in the field of environment, mining companies are also less open and responsive to provide and provide data or information needed by field supervisors, by delegating the authority to provide ecological to the company's headquarters who are in Jakarta. This condition creates field information from observations to verify the company's performance in Minister of Environment Regulation No. 06 of 2013 and No. 101 of 2014 concerning waste management that is hazardous and toxic materials is challenging to confirm factually.

The implementation of supervision is also less effective and overleaping because it is carried out by the provincial government and district governments partially and not collaboratively. This condition makes the information obtained becomes different and overlapping between government agencies, even though the two institutions are representations of government agencies. Differences in authority and institutional ego make collaboration in the implementation of company compliance monitoring not effective and efficient.

\section{CONCUSSION}

The results of these studies generally concluded that the implementation of the EIA policy of mining companies in Gorontalo Regency compliance with the implementation of environmental regulations in the licensing process and environmental management controlled by the government with a command-and-control approach. Accurately summarized some things as follows:

1. The Issuance of Environmental Permit for Mining Companies in Gorontalo Regency has been carried out optimally by following the mechanism stipulated in the environmental permit regulation policy by involving the community in the process of preparing and evaluating the feasibility of environmental documents.

2. Compliance Mining companies in the implementation of EIA in Gorontalo are quite useful because they have environmental permits and are consistent in monitoring and handling wastewater as well as providing storage of toxic and hazardous materials (B3) following the provisions of the legislation in Indonesia. 
3. The supervision of the Gorontalo Provincial Government has been carried out routinely directly, indirectly and incidentally. However, the control implementation has not maximized in terms of the availability of functional regional environmental supervisors, the application of separate supervision between provincial and district governments which has resulted in overlapping different supervision and treatment activities of companies, and lacking transparency in mining companies in providing field status data.

\section{REFERENCE}

Abdul Hafiz. 2016. Dampak Izin Pertambangan Batubara bagi Lingkungan Masyarakat Keluarahan Sempaja Timur Samarinda Utara (Impact of Coal Mining Permit for the Community Environment of Sempaja Timur Village, North Samarinda). eJournal Ilmu Pemerintahan. Vol 4. No. 4. Hal. 1651-1660

Allen R. 1980. How to Save The World. New Jersey: Barnes and Noble;

Anderson, J. E. 2003. Public Policy Making. Fifth Edition. Boston: Houghton Mifflin Company

Arnstein, Sherry R. 1969. A Ladder of Citizen Participation. JAIP. Vo. 35. No. 4, Juli 1969. Pp. $216-224$.

Arifin, Bustanul \& Didik J. Rachbini. 2001. Ekonomi Politik dan Kebijakan Publik (Political Economy and Public Policy). Jakarta: PT Grasindo

Baumgärtner S, Quaas M. What is Sustainability Economics? Ecol Econ 2010-69. Hal. 445-50.

Bhandari, Deepika; Garg, Rakesh Kumar, 2016. Effect of Industrialization on Environment (India Scenario). Global Journal For Research Analysis. Volume-4, Issue-12, Dec-2015

Cohen, Steven. 2006. Understanding Environmental Policy. New York: Columbia University Press

Decree of the Minister of Environment No. 07 of 2001 concerning Officials of Environmental Supervision and Official of Regional Environmental Supervisors

Dye R Thomas. 2008. Understanding Public Policy. Pearson Education' Upper Saddle River' NewJersey

Hasibuan, Malayu, S.P. 2005. Manajemen - Dasar, Pengertian, dan Masalah (Management: Basic, Understanding and Problem). Jakarta:Bumi Aksara

Environmental Performance Index. 2018. Global Metrics for the Environment: Ranking Country Performance on High-Priority Environmental Issue. Yale Center for Environmental Low \& Policy, Yale University.

Fachlevi, T. A; Keumala Putri, E.I; Simanjuntak, S. M.H. 2015. Dampak dan Evaluasi Kebijakan Pertambangan Batubara di Kecamatan Mereubo (Impact and Evaluation of Coal Mining Policies in Mereubo District). Risalah Kebijakan Pertanian dan Lingkungan. Vol. 2 No. 2. Agustus 2015. Hal. 171-180.

Fiorino, Daniel J. The New Environmental Regulation. Cambridge, Ma.: The MIT Press, 2006

Gasparatos A, El-Haram M, Horner M. 2008. A Critical Review Of Reductionist Approaches For Assessing The Progress Towards Sustainability. Environ Impact Assess Rev -28: Hal. 286-311.

Government Regulation No. 27 of 2012 concerning Environmental Permits

Hidayat, A. F \&Basuki, A. 2014. Perizinan Lingkungan Hidup Dan Sanksi Pidana Bagi Pejabat Pemberi Izin. Perspektif, Vol. 19, No. 2, Pp. 94-103

Hrebicek, J; Soukopova, J; \& Kutova, E. 2010. Standarization of Key Performance Indicators for Environmental Management and Reporting in The Czech Republic. International Journal of Energy and Environment. Issue 4. Volume 4. Hal. 169-176

Jordan, A. J \& Lenschow, A. 2008. Innovation in Environmental Policy? Integrating the Enviromental for Sustainability. Northampon: Edward Elgar Publishing

Kates RW, Clark WC, Corell R, et al. 2001. Sustainability science. Science;292(5517): 641-2.

Kolb, Eugene J., 1978. A Framework for political Analysis, New York: Prentice Hall.

Law No. 4 of 1982 concerning the Principles of the Environme

Law No. 23 of 1997 concerning Environmental Management

Law No. 32 of 2009 concerning Environmental Protection and Management.

Madarang, Kristina M. 2014. Environmental Policy Instrument (Direct Regulation, Market-Based Tools, and Voluntary Programs): Better Together.https://www.researchgate.net/publication/319682083DOI: 10.13140/RG.2.2.23240.83202

Mekuriaw, Asnake \& Belay Teffera. 2013. The Role Of Environmental Impact Assessment For Sustainable Development. IAIA13 Conference Proceedings. Calgary, Alberta, Canada www.iaia.org

Miles, M.B., Huberman, A.M., Saldana, J. 2014. QualitativeData Analysis: AMethods Sourcebook.. SAGE Publications Inc: Thousand Oaks, United States

Minister of Environment Regulation No. 08 of 2013 concerning Management of Assessment and Examination of Environmental Documents and Issuance of Environmental Permits

Minister of Environment Regulation No. 08 of 2013 concerning the Management and Assessment of Environmental Documents and Issues of Environmental Permits

Minister of Environment Regulation No. 27 of 2009 concerning Guidelines for Implementing Strategic Environmental Studies.

Minister of Environment Regulation No. 06 of 2013 concerning Corporate Performance Rating Program in 
Environmental Management

Minister of Environment Regulation No. 17 of 2012 concerning the Community Engagement Program in the Process of Environmental Impact Analysis and Environmental Permits.

Minister of Environment Regulation No. 101 of 2014 concerning Management of Hazardous and Toxic Material Waste

Muhjad, M. Hadin, 2015, Hukum Lingkungan: Sebuah Pengantar untuk Konteks Indonesia (Environmental Low: An Introduction to the Indonesian Context), Yogyakarta: Genta Publishing.

Munn R.E. 1979.Environmental Impact Assessment: Principles And Procedures. 2nd Edition. John Wiley, New York

Mustofa, H.A. 2005. Kamus Lingkungan (Dictionary of the Environment). Jakarta: Penerbit Rineka Cipta

Nugroho, Riant. 2014. Kebijakan Publik di Negara-Negara Berkembang (Public Policy in . Developing Countries) Yogyakarta: Pustaka Pelajar

2014. Kebijakan Sosial Untuk Negara Berkembang (Social Policy for Developing Country). Yogyarkarta: Pustaka Pelajar

Ogola, Pacifica F. Achieng. 2007. Environmental Impact Assessment General Proceduress. https://orkustofnun.is/gogn/unu-gtp-sc/UNU-GTP-SC-05-28.pdf

Paul, Bac Dorin. 2008. A History of The Concept of Sustainable Development: Literature Review. http://www.cfr.washington.edu/classes.esrm.458/Paul.\%202008.pdf

Pellikaan, H \& Van der Veen, R. J. 2004. Environmental Dillemas and Policy Design. United Kingdom: Cambridge University Press

Petts, Judith. 1999. Handbook of Environmental Impact Assesment. Volume 2: Environmental Impact Assesment in Practice: Impact and Limitaton. Blecwell Science

Rahmadi, T. 2011. Hukum Lingkungan di Indonesia (Environmental Low in Indonesian). Jakarta: Raja Grafindo Persada.

Rithi, H \& Pudyatmoko, 2016. Kebijakan Perizinan Lingkungan hidup di Daerah Istimewa Yogyakarta (The Environmental Licensing Policy in the Special Region of Yogyakarta). Mimbar Hukum. Volume 28, Nomor 2, Hal. 263-276.

Resosudarmo, Budy P.; Irhamni, Milda. 2008. Indonesia's industrial policy reforms and their environmental impacts. Journal of the Asia Pacific Economy. Vol. 13, No. 4, November 2008. Hal. 426-450 Doi: $10.1080 / 13547860802364752$

Ridwan, HR, 2006, Hukum Administrasi Negara (State Administrative Low), Rajawali Pers, Jakarta

Risal, S; Paranoan, DB; Djaja, S. 2013. Analisis Dampak Kebijakan Pertambangan terhadap Kehidupan Sosial Ekonomi Masyarakat di Keluarhan Makroman (Analysis of the Impact of Mining Policy on Community SocioEconomic Life in Makroman Sub-District). eJournal Administration Reform. Vo. 1. No. 1. Hal 117-131.

Siahaan, N.H.T. 2008. Hukum Lingkungan (Environmental Low). Jakarta: Pancuran Alam.

Siagian, Sondang. 2008. Manajemen Strategi (Strategic Management). Jakarta: Bumi Aksara

Wanto. M. Santro. 2012. Anomali Pengelolaan Sumber Daya Alam Di TingkatLokal Dalam Perspektif Ekonomi Politik (Anomalies in the Management of Natural Resources at the Local Level in a Political Economy Perspective). Pelangi Ilmu. Vol 5. No. 5. Hal. 1-11.

Wibisana, Andri G. 2017. Campur Tangan Pemerintah dalam Pengelolaan Lingkungan: Sebuah Penelusuran Teoritis berdasarkan Analisis Ekonmi atas Hukum (Government Interference in Environmental Management: A Theoretical Search based on Ekonmi's Analysis of Law). Jurnal Hukum \& Pembangunan Vol. 47 No. 2. Hal 151-182

World Commission on Environment and Development (WCED). Our common future. Oxford Paperbacks; 1987.

Vogler, J. 2007. The International Politic of Sustainable Development. Chaptersin: Handbook of Sustainable Development, chapter 26 Edward Elgar Publishing.

Vos, H. Direct Regulation and Economic Instruments: Antagonist or Allies in C. Jeanrenaud (ed). 1997. Environmental Policy Between Regulation and Market. Verlag Basel: Switzerland.

Yakin, Sumadi Kamarol. 2017. Analisis Mengenai Dampak Lingkungan (AMDAL) sebagai Instrumen Pencegahan Pencemaran dan Kerusakan Lingkungan (Environmental Impact Analysis (EIA) as an Instrument for Pollution Prevention and Environmental Damage). Badamai Law Journal. Vol. 2. Issues 1. Maret 2017. Hal. 113-132 